\begin{tabular}{|l|c|c|c|}
\hline $\begin{array}{l}\text { Окружность груд. } \\
\text { клетки, см }\end{array}$ & & & \\
-основная группа & $70,71 \pm 1,56$ & $71,47 \pm 1,0(62-82)$ & $75,3 \pm 1,86$ (73-79) \\
-сравнительная группа & $(61-91) 70,24 \pm 1,99$ & $72,80 \pm 1,03$ & $76,79 \pm 0,22$ \\
\hline Р & $(60-96)$ & $(61-99)$ & $(66-100)$ \\
\hline Длина ноги, см & $>0,05$ & $>0,05$ & $>0,05$ \\
-основная группа & $93,5 \pm 1,91$ & $93,1 \pm 1,1(78-103)$ & $93,3 \pm 0,84(94-97)$ \\
-сравнительная группа & $(79-104) 79,24 \pm 1,40$ & $81,67 \pm 0,93$ & $82,87 \pm 0,97$ \\
\hline \multicolumn{1}{|c|}{ Р } & $(73-100)$ & $(75-103)$ & $(72-105)$ \\
\hline \multicolumn{2}{|r|}{} \\
\hline
\end{tabular}

Таким образом, у девочек с синдромом ГА отмечается существенное увеличение ширины плеч в динамике полового созревания. При сравнении с физиологическими показателями отмечаются высокие показатели ширины плеч и длины ноги на фоне уменьшения показателя размаха рук. Полученные показатели позволили утверждать, что у девочек с синдромом ГА в динамике периода полового созревания преобладает андроидный тип телосложения.

$$
* * *
$$

1. Коколина В.Ф. Детская и подрастковая гинекология // М., Медпрактика, 2012, 680 с.

2. Кузнецова И.В. Девочка-подросток - как пациент. Эндокринная гинекология физиологического пубертата: оптимальный минимум коррекции // Информативный бюллетень. Редакция журнала StatusPraesens, 2014, 20 c.

3. Левенец С.А., Нечетова Т.А. Гиперпролактинемия у девушек-подростков с нарушениями менструальной функции и методы ее коррекции // Здоровье женщины, 2010, №4, с.127-128.

4. Наджи Л.А., Алиева Э.М. Особенности физического развития девочек с физиологическим течением периода полового созревания // Достижения медицинской науки Азербайджана.-2010.-№4.-səh 47-50.

5. Петеркова В.А., Семечева Т.В., Горелышев С.К. Преждевременное половое развитие. Клиника, диагностика, лечение: Пособие для врачей. М., 2013, 40 с.

6. Полтава Н.В. Эндокринные нарушения репродуктивного здоровья девочек-подростков и современные возможности их гормональной коррекции и профилактики // Автореф. дисс. ... канд.мед.наук: 14.01.01, Бишкек, 2017, 25 с.

7. Ящук А.Г. Формирование репродуктивной системы девочек-подростков в современных условиях // Репродуктивное здоровье детей и подростков, 2012, №6, с.30-44.

8. Bauman D. Diagnostic methods in pediatric and adolescent gynecology // Endocrine development, 2012, vol.22, p.40-55.

9. Fruzzetti F., Campagna A.M., Perini D., Carmina E. Ovarian volume in normal and hyperandrogenic adolescent women //Fertil Steril., 2015, №104, p.196-199.

10. Georgopoulos N.A., Kandaraki E., Panidis D.Hyperandrogenism in PCOS // Fertil.Steril., 2009, №3, p.1-6.

\title{
Garashova M.A. \\ Incidence of tumors of the reproductive system in the postmenopausal period in the republic of Azerbaijan
}

Azerbaijan Medical University (Azerbaijan, Baku)

doi: $10.18411 / g d s n-25-12-2019-16$

idsp: scienceconf-25-12-2019-16

\section{Abstract}

Purpose: Determination of the frequency of occurrence of genital tumors in women in the postmenopausal period in the conditions of the Azerbaijan.

Materials and methods. A retrospective study of case histories of 301 women with tumors of the reproductive organs in the postmenopausal period. The average age of patients was $61.6 \pm 0.4$ years. The duration of the postmenopausal period was $11.0 \pm 0.6$ years.

The results of the study. In the postmenopausal period there was manifestation of the uterine fibroids in $28.9 \%$ of patients. $22.9 \%$ of patients had endometrial hyperplasia, $21.6 \%$ had 
endometrial cancer, $10.6 \%$ had ovarian cancer and $8.6 \%$ of women were diagnosed cervical cancer. There was confirmed, that the incidence of benign genital tumors in postmenopausal women was $57.4 \%$, the incidence of malignant tumors was $42.6 \%$.

Key words: postmenopausal period, uterine myoma, endometrial hyperplasia, ovarian cancer, cervical cancer, serous adenocarcinoma, mucinous adenocarcinoma, atypical hyperplasia.

\section{Аннотация}

Цель: определение частоты встречаемости опухолей гениталий у женщин в постменопаузальном периоде в условиях Азербайджанской Республики.

Материал и методы. Проведено ретроспективное исследование историй болезни 301 женщины с опухолями репродуктивных органов в постменопаузальном периоде. Средний возраст больных составил $61,6 \pm 0,4$ года. Длительность постменопаузального периода была $11,0 \pm 0,6$ лет.

Результаты исследования. В постменопаузальном периоде у 28,9\% больных отмечались клинические проявления миомы матки, у 22,9\% больных гиперпластические процессы эндометрия, у 21,6\% рак эндометрия, у 10,6\% рак яичников и у $8,6 \%$ женщин был диагностирован рак шейки матки. Частота доброкачественных опухолей гениталий в постменопаузе составила $57,4 \%$, частота злокачественных опухолей составила $42,6 \%$.

Ключевые слова: постменопаузальный период, миома матки, гиперплазия эндометрия, рак яичников, рак шейки матки, серозная аденокарцинома, муцинозная аденокарцинома, атипическая гиперплазия.

Tumors of the reproductive tract include a large number and variety of benign and malignant neoplasms of the external and internal genital organs. Despite the variety of nosologies that determine the structure of cancer incidence, according to the International Agency for Research on Cancer (IARC), malignant tumors of the reproductive system account for $35 \%$ of all malignant tumors. Annually, 2.1 million women are diagnosed with breast cancer, and 1.2 million women with genital neoplasms worldwide [5].

During the process of aging on the background of extinction of the ovarian steroid synthesis there are also the reaction of cells and tissues of various target organs to hormonal and metabolic changes observed. Changes in hormones do not affect the structure of DNA and do not cause cancer, but at the same time, hormones can induce cancer $[2,3,6]$.

It was revealed that one of the causes of reproductive system tumors is the complex mechanism of neuroendocrine regulation failure. There were established following mechanisms of the genital tumors development:

- A primary decrease in the functional activity of the ovaries, including a decrease in the level of ovarian estrogens;

- Compensatory increase in the level of gonadotropins, particular FSH;

- Stimulating effect of elevated gonadotropins level on proliferating epithelium;

- The development of diffuse and then focal endometrial hyperplasia [1,5,7].

The goal of the study was to determine the frequency of genital tumors in the postmenopausal period in the conditions of the Azerbaijan Republic.

Materials and methods. Based on the purpose of the study, a retrospective study of case histories of 301 women in the postmenopausal period was conducted. All patients were examined and received appropriate treatment at the Oncology Clinic of the Azerbaijan Medical University.

The average age of women was $61.6 \pm 0.4$ and ranged from 46 to 83 years. The duration of the postmenopausal period was within $11.0 \pm 0.6(2-34)$ years.

Research results and discussion. The structure of tumors of the reproductive system in women in the postmenopausal period is presented in figure.

As can be seen from the scheme, of 301 patients, 87 (28.9\%) had clinical manifestations of uterine fibroids. In 69 patients $(22.9 \%)$, clinical and diagnostic manifestations of endometrial hyperplastic processes were determined. In 65 patients $(21.6 \%)$, endometrial cancer was 
detected. Ovarian cancer was diagnosed in $32(10.6 \%)$ patients. $26(8.6 \%)$ women were diagnosed with cervical cancer.

During the present study, the structure of endometrial hyperplastic processes was determined. It was found out that the frequency of complex endometrial hyperplasia with atypia was $12.3 \%$ (in 37 patients). The incidence of endometrial hyperplasia without atypia was within $10.6 \%$. Of these, the frequency of diffuse hyperplasia was $6.3 \%(\mathrm{n}=19)$, focal hyperplasia (polyps) $4.3 \%(n=13)$.

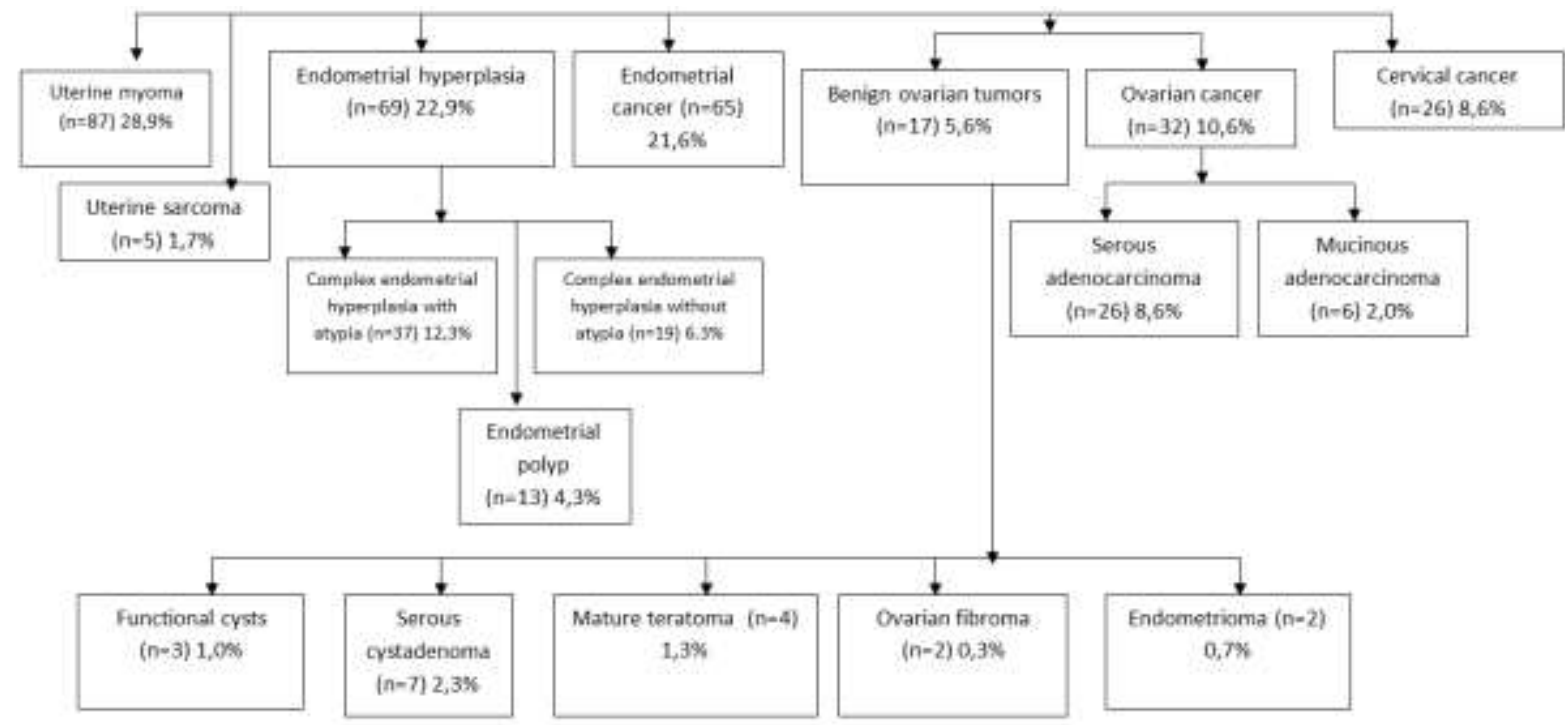

Figure. The structure and incidence of genital tumors in postmenopausal period

According to a retrospective study, in the postmenopausal period, patients with ovarian cancer $(n=32)$ in $8.6 \%$ of cases had serous adenocarcinoma, in $2 \%$ of cases mucinous adenocarcinoma.

As a result of the study, it was found out that the incidence of benign ovarian tumors was $5.6 \%$. Moreover, serous cystadenoma $(2.3 \%)$, mature teratoma $(1.3 \%)$ prevailed in the structure of benign ovarian neoplasms. It should be noted that almost the same frequency was observed in incidence of endometrioma ( $0.7 \%)$, ovarian fibroma $(0.3 \%)$, and functional ovarian cysts $(1.0 \%)$.

Thus, in the postmenopausal period, clinical and diagnostic manifestations of uterine fibroids were determined in $28.9 \%$ of patients, endometrial hyperplastic processes in $22.9 \%$, endometrial cancer in $21.6 \%$, ovarian cancer in $10.6 \%$ of patients. $8.6 \%$ of women were diagnosed with cervical cancer. At the same time, in the structure of genital tumors the proportion of benign neoplasms prevailed and was diagnosed in $57.4 \%$, malignant neoplasms in $42.6 \%$ of cases.

$* * *$

1. Ciarmela P., Islam M.S., Reis F.M. Growth factors and myometrium: biological effects in uterine fibroid and possible clinical implications // Hum.Reprod.Update, 2011, vol.17, №6, p.772-790.

2. Collaborative Group On Epidemiological Studies Of Ovarian Cancer, Beral V, Gaitskell K, Hermon C, Moser K., Reeves G., Peto R. Menopausal hormone use and ovarian cancer risk: individual participant metaanalysis of 52 epidemiological studies // Lancet., 2015, №385, p.1835-1842.

3. Dossus L., Allen N., Kaaks R., Bakken K., Lund E. Reproductive risk factors and endometrial cancer: the European Prospective Investigation into Cancer and Nutrition // Int.J.Cancer., 2010, №127, p.442-451.

4. Han K.H., Park N.H., Kim H.S., Chung H.H. Peritoneal cytology: A risk factor of recurrence for nonendometrioid endometrial cancer // Gynecol. Oncolog., 2014, №134, p.293-296.

5. IARC Biennial Report 2008-2009. Lyon: International Agency for Research on Cancer, 2009, 145 p.

6. $\quad$ Lee A.W., Ness R.B., Roman L.D., Terry K.L. Association Between Menopausal Estrogen-Only Therapy and Ovarian Carcinoma Risk // Am.J.Obstet.Gynecol., 2016, vol.127, №5, p.828-836.

7. $\quad$ Pearce C.L., Templeman C., Rossing M.A., Lee A., Near A.M. Association between endometriosis and risk of histological subtypes of ovarian cancer: a pooled analysis of case-control studies // Lancet Oncol., 2012, №13, p.385-394. 